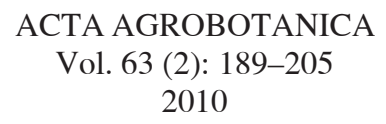

\title{
STUBBLE FIELD PLANT COMMUNITIES OF THE MAZOWIECKI LANDSCAPE PARK
}

\author{
Teresa Skrajna, Maria Ługowska
}

The Agricultural Ecology Department of the University of Podlasie in Siedlce, B. Prusa 14, 08-110 Siedlce, Poland, e-mail: ekorol@ ap.siedlce.pl

Received: 15.08 .2010

$$
\text { Abstract }
$$

The characteristics of communities found in unploughed stubble fields of the Mazowiecki Landscape Park and its agricultural buffer zone are presented in the paper. The association Echinochloo-Setarietum divided into a typical variant, the variant with Galinsoga parviflora, and the variant with Bidens tripartite, was the most frequently noted and floristically differentiated association. Patches of Digitarietum ischaemi were also frequently observed in stubble fields on the poorest habitats. Rarely, on fertile soils, small patches of floristically rich communities with Veronica agrestis were recorded. Periodically, excessively wet habitats were seldom occupied by the speciesrichest phytocoenoses of Centunculo-Anthoceretum punctati. Single patches of the community with Setaria pumila, the form with Aphanes arvensis, were observed only in the south-eastern part of the Park.

Key words: stubble field, weed communities, phytosociological characteristics, Mazowiecki Landscape Park

\section{INTRODUCTION}

Communities developing in unploughed stubble fields are distinguishable by their specific floristic composition. A few different groups of plants are found there: the remains of cereal agrophytocoenoses, weed species typical for root crops as well as taxa characteristic of ruderal and semi-natural communities (especially meadow ones). The species composition of these heterogeneous communities is closely related to habitat conditions ( $\mathrm{Tr}$ ą $\mathrm{ba}$, 1993; Skrajna and Skrzyczyńska, 2002; Rzymowska and Skrzyczyńska, 2006a,b). Favourable development conditions, which predominate in stubble fields, stimulate the growth of weeds that flower and fruit abundantly, enriching soil-seed reserves (Pawłowski et al. 1970; Trąba and Zi e mińs ka, 1994; Ję d r u s zcza k, 1997).
The present paper is a part of a series on segetal vegetation of the Mazowiecki Landscape Park (Fig. 1) in which information concerning the classification and phytosociological characteristics of stubble field communities was published. Detailed data on the area and research methods were presented in the previous paper ( $\mathrm{S} \mathrm{k} \mathrm{raj} \mathrm{n} \mathrm{a} \mathrm{et} \mathrm{al.} \mathrm{2009).} \mathrm{The} \mathrm{characteristics} \mathrm{of} \mathrm{stubble}$ field phytocoenoses developing within the area of the Mazowiecki Landscape Park were determined on the basis of 114 phytosociological relevés made according to the B raun-B lanquet method(P a w łow ski, 1972). Systematics and nomenclature of plant associations are based on Matus zkiewicz (2001). Species nomenclature follows M i r e k et al. (2002).

\section{RESULTS}

Systematics of the distinguished stubble field associations and communities

Class: Stellarietea mediae Tx., Lohm. et Prst. 1950

Order: Polygono-Chenopodietalia (R.Tx. et Lohm. 1950) J. Tx.

Alliance: Panico-Setarion Siss. 1946

1. Association: Digitarietum ischaemi R. Tx. et Prsg (1942) 1950

a. typical variant

b. variant with Anthoxanthum aristatum

c. variant with Polygonum hydropiper

Community with Setaria pumila

a. typical form

b. form with Aphanes arvensis

2. Association: Echinochloo-Setarietum Krusem. et Vlieg. (1939) 1940

a. typical variant

b. variant with Galinsoga parviflora

c. variant with Bidens tripartita

Alliance: Polygono-Chenopodion

Community with Veronica agrestis 
Class: Isoëto-Nanojuncetea Br.-Bl.et R. Tx. 1943

Order: Cyperetalia fusci (Klika 1935) Müller-Stoll et Pietsch 1961

Alliance: Radiolion linoidis (Rivas Goday 1961) Pietsch 1965

3. Association: Centunculo-Anthoceretum punctati (Koch 1926) Moor 1936

a. typical variant

b. variant with Hypericum humifusum

c. variant with Centaurium pulchellum

Characteristics of the distinguished associations and communities 1950

Digitarietum ischaemi R. Tx. et Prsg (1942)

Patches of Digitarietum ischaemi were noted in rye stubble fields on the poorest sandy soils of very weak and weak rye complex as well as cereal-fodder weak complex. The patches occurred equally frequently within the area of the Park and in its agricultural buffer zone. The association was characterized by 30 relevés, of which 10 represent the typical variant, 10 - the variant with Anthoxanthum aristatum, and 10 - the variant with Polygonum hydropiper (Table 1). The typical variant patches were noted in the poorest habitats from among all those occupied by that association. The characteristic species - Digitaria ischaemum - reached the highest cover index there. Phytocoenoses of the variant with Anthoxanthum aristatum were floristically poorest. The average plant cover was only $20 \%$. The wet variant patches were recorded in stubble fields situated in local depressions, usually on periodically excessively wet areas. These phytocoenoses were distinguishable by the mass occurrence of hygrophilous weeds, e.g.: Polygonum hydropiper and Bidens tripartita. In total, 65 species were noted in all the plots of this association (38 in the typical variant, 28 in the variant with Anthoxanthum aristatum, and 57 in the variant with Polygonum hydropiper). The average number of species per relevé varied from 11 in the patches of the variant with Anthoxanthum aristatum to 21 in the wet variant.

\section{Community with Setaria pumila}

The community was frequently recorded in the stubble fields of the Mazowiecki Landscape Park and its buffer zone (Table 2). It was distinguishable by the mass occurrence of Setaria pumila and a high proportion of acidophilous weeds, e.g. Spergula arvensis, Scleranthus annuus and Anthemis arvensis. A low percentage of the species characteristic of the PanicoSetarion alliance was also noted. The typical form of the community was observed in the whole study area, mainly in rye stubble fields on poor sandy soil of weak rye complex. Patches with the mass occurrence of Aphanes arvensis were noted only in stubble fields situated in the following localities: Kąty, Skorupy, Augustówka, Łukowiec, and Gózd. Patches of this community were developing on sandy muck and silt-peaty soils of periodically excessively wet cerealfodder weak complex, which resulted in a high proportion of hygrophilous weed species, e.g. Polygonum hydropiper, Polygonum amphibium, Plantago intermedia, Gnaphalium uliginosum. In this area, the impoverished association of Aphano-Matricarietum was observed in cereal crops.

Echinochloo-Setarietum Krusem. et Vlieg. (1939) 1940

Patches of the association Echinochloo-Setarietum were observed most frequently in unploughed cereal stubble fields of the studied area (Table 3). Among the characteristic species, Echinochloa crus-galli occurred in large numbers, Raphanus raphanistrum was noted less frequently. Patches of this phytocoenosis developed in various trophic and moist conditions. Patches of the typical variant were usually recorded on good rye complex soils. They were floristically poorest among all identified variants of the association (on average, 21 species in one relevé) and marked by the highest cover of Echinochloa crus-galli.

In a close vicinity of buildings, on more fertile nitrogen-rich soils classified as good and very good rye complex, there were noted patches of the variant with the abundant occurrence of Galinsoga parviflora. A large proportion of weeds characteristic of the Polygono-Chenopodion alliance, which includes species with high nutrient demands, e.g.: Veronica persica, Galinsoga ciliata and Chenopodium polyspermum, was observed in these phytocoenoses.

The floristically richest patches of this association, classified as the variant with Bidens tripartita, were observed in stubble fields on soils developed from clayey soils and common dusts, classified as good and very good rye complex and strong cereal-fodder complex. They were distinguishable by the mass occurrence of hygrophilous weed species, e.g. Bidens tripartita, Plantago intermedia, Polygonum hydropiper, Stachys palustris, and Sagina procumbens. This variant comprised 92 taxa, on average 30 species in one relevé.

\section{Community with Veronica agrestis}

Patches of the community with Veronica agrestis were noted very seldom in stubble fields of the Mazowiecki Landscape Park and its buffer zone. The species characteristic of the Polygono-Chenopodion alliance, with high trophic and $\mathrm{pH}$ requirements, predominated in their floristic composition (Table 4). Apart from Veronica agrestis occurring in large numbers, a few other taxa occurred with a high constancy and cover, e.g. Matricaria maritima subsp. inodora, 


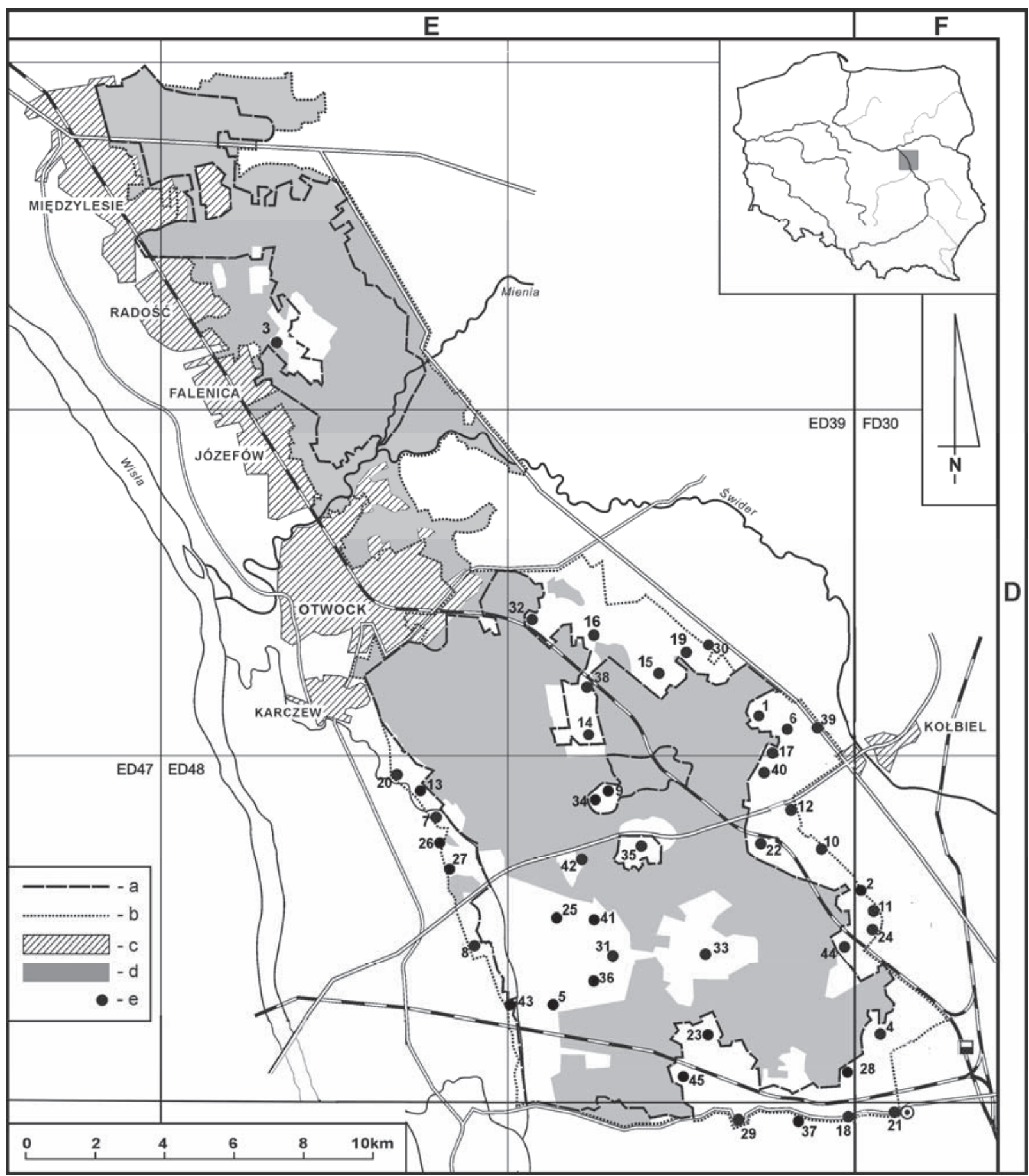

Fig. 1. Investigated area

$\mathrm{a}$ - borders of the Landscape Park; $\mathrm{b}$ - borders of the protected zone; $\mathrm{c}$ - building grounds

$\mathrm{d}$ - forest complexes; e - localities, inwestigated areas

1 - Anielinek, 2 - Antoninek, 3 - Aleksandrówka, 4 - Augustówka, 5 - Bąki, 6 - Bocian, 7 - Brzezinka, 8 - Całowanie, 9 - Celestynów, 10 - Chrosna, 11 - Chrząszczówka, 12 - Człekówka, 13 - Dąbrowa, 14 - Dąbrówka, 15 - Dyzin, 16 - Glina, 17 - Gózd, 18 - Grabianka, 19 - Jatne, 20 Janów, 21 - Jaźwiny, 22 - Karpiska, 23 - Kąciki, 24 - Kąty, 25 - Kominki, 26 - Kozłówka, 27 - Łukowiec, 28 - Ocznia, 29 - Osieck, 30 - Ostrowik, 31 - Podbiel, 32 - Pogorzel, 33 - Ponurzyca, 34 - Radzyń, 35 - Regut, 36 - Rosłańce, 37 - Rudnik, 38 - Stara Wieś, 39 - Stara Wieś II, 40 - Skorupy, 41 - Szatany, 42 - Tabor, 43 - Warszówka, 44 - Zabieżki, 45 - Zawada 


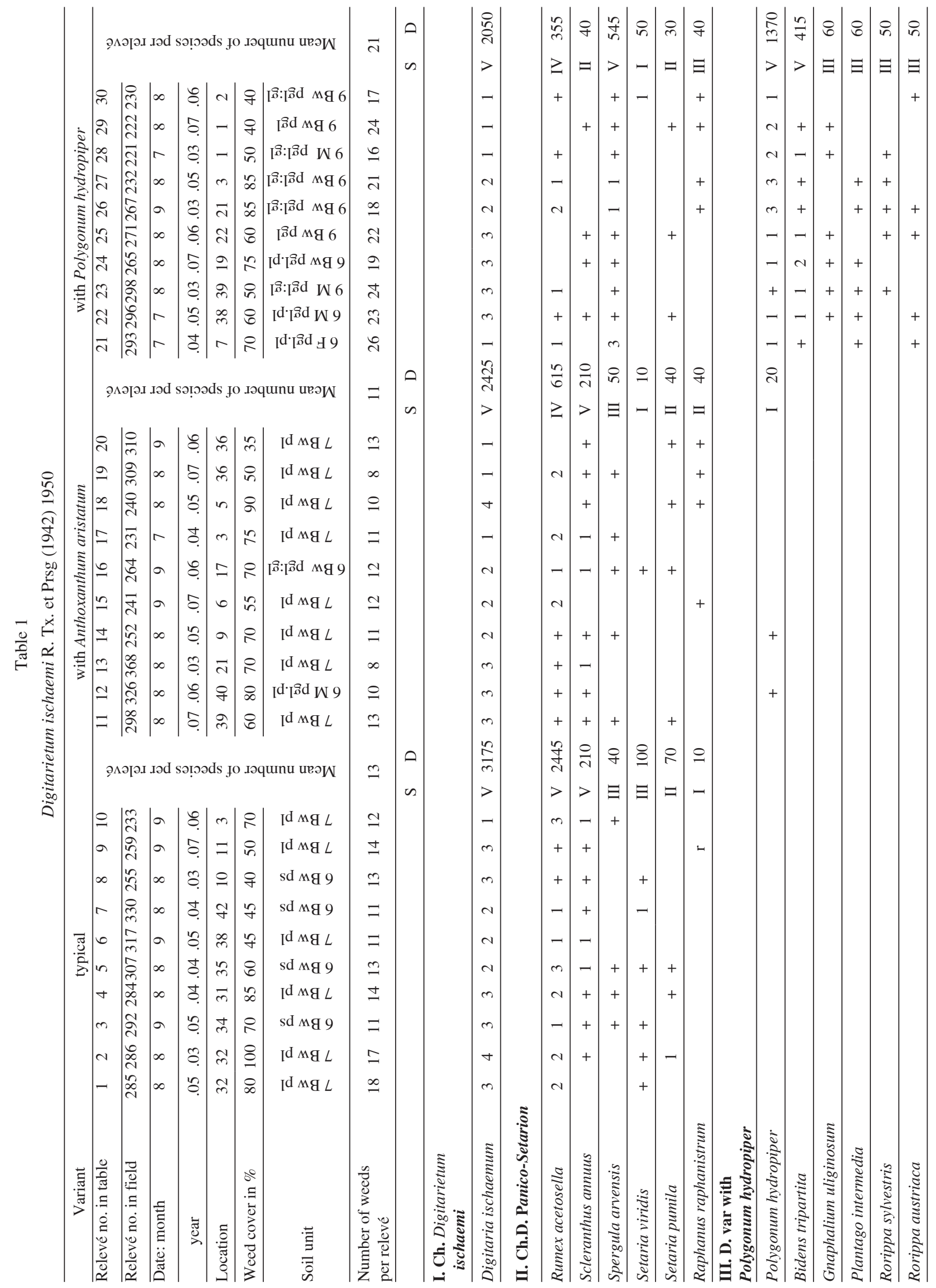




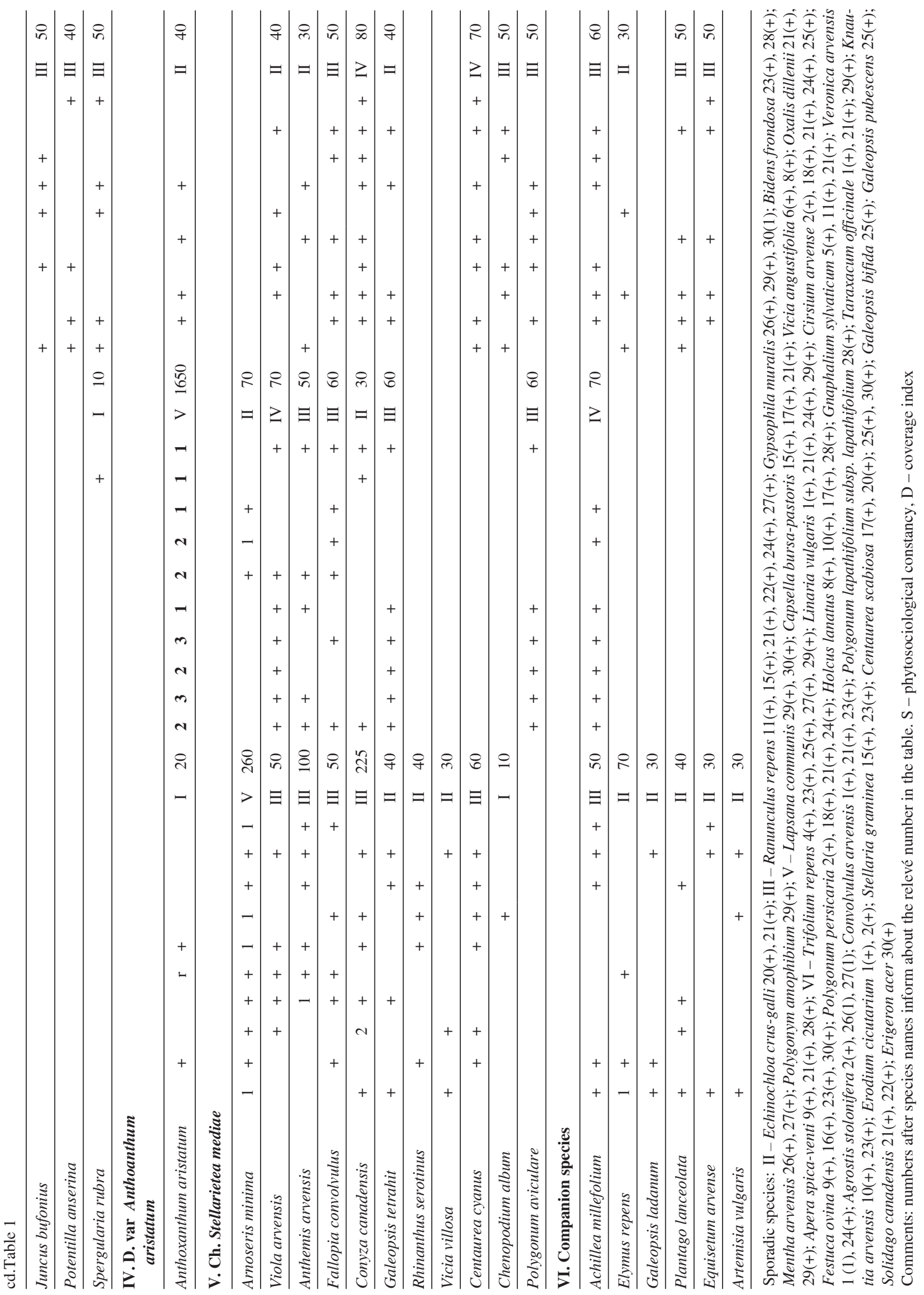




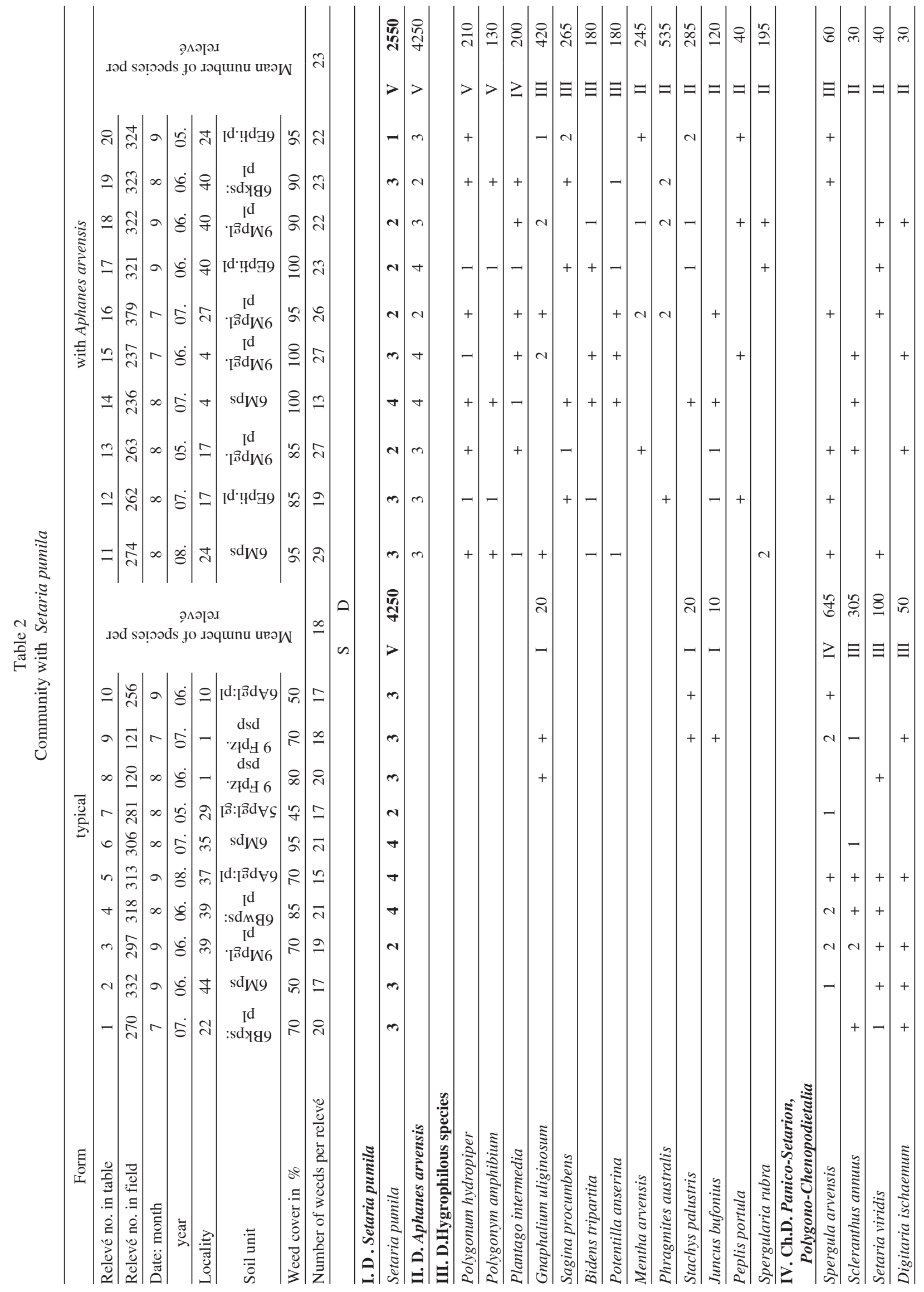




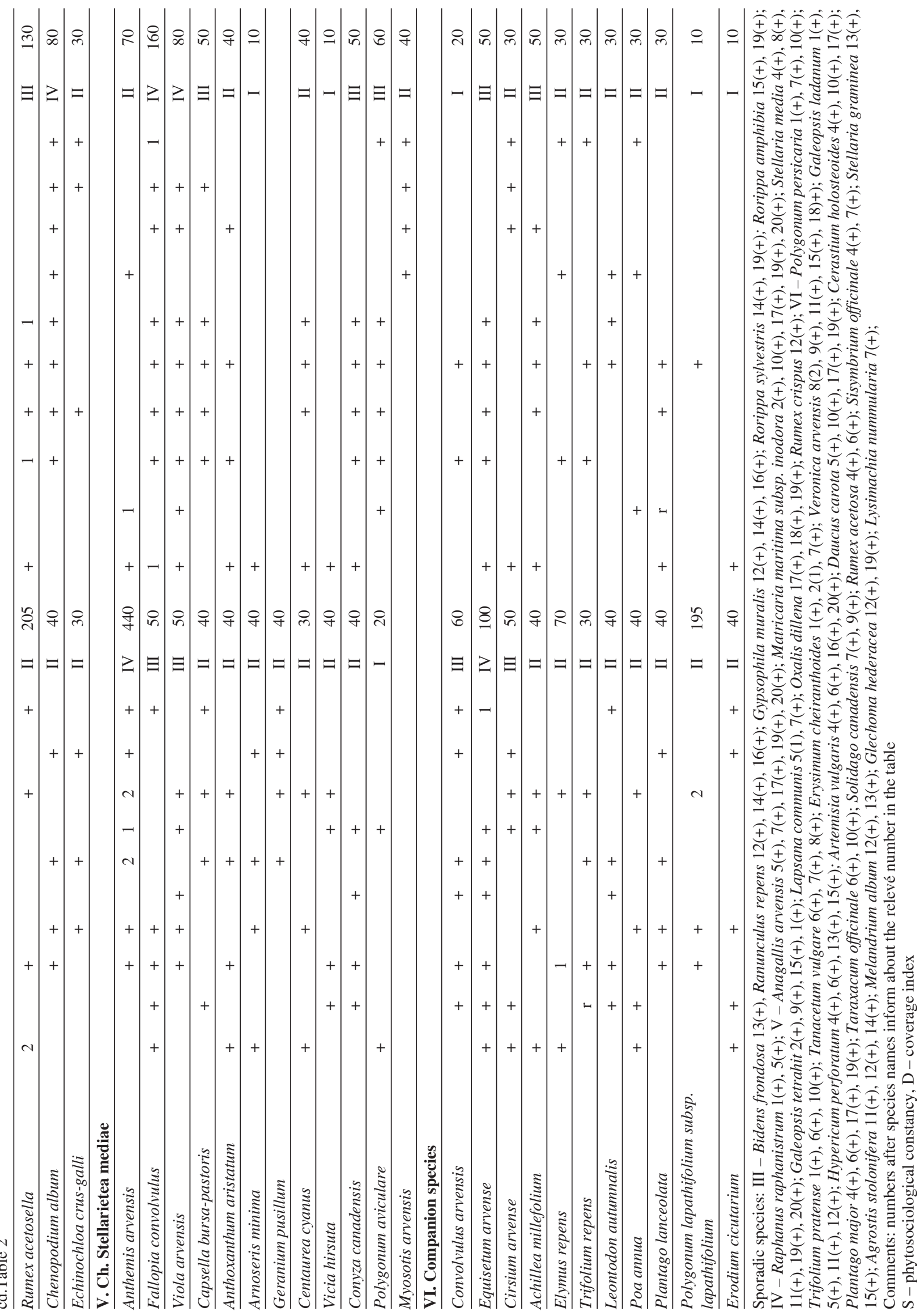




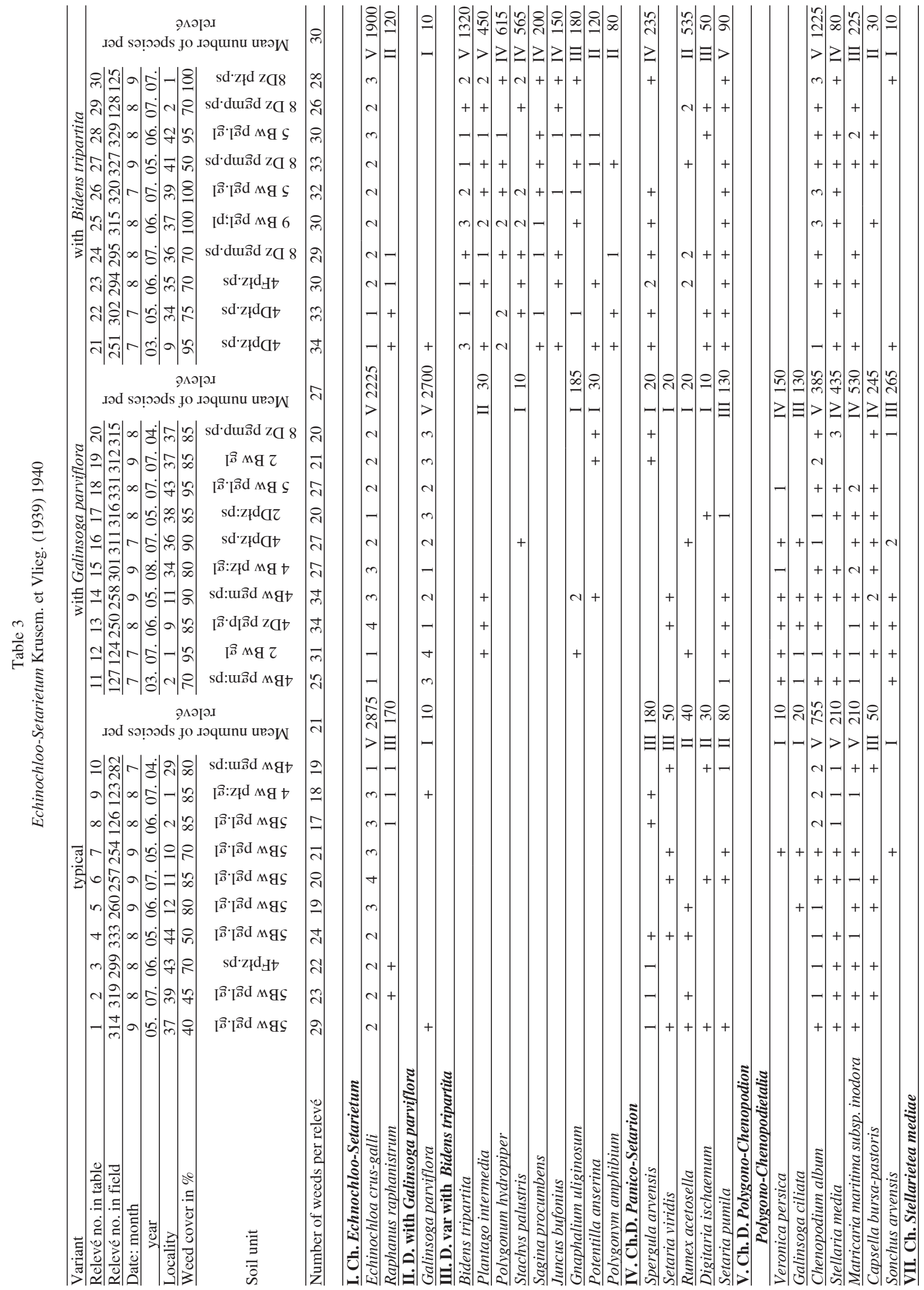




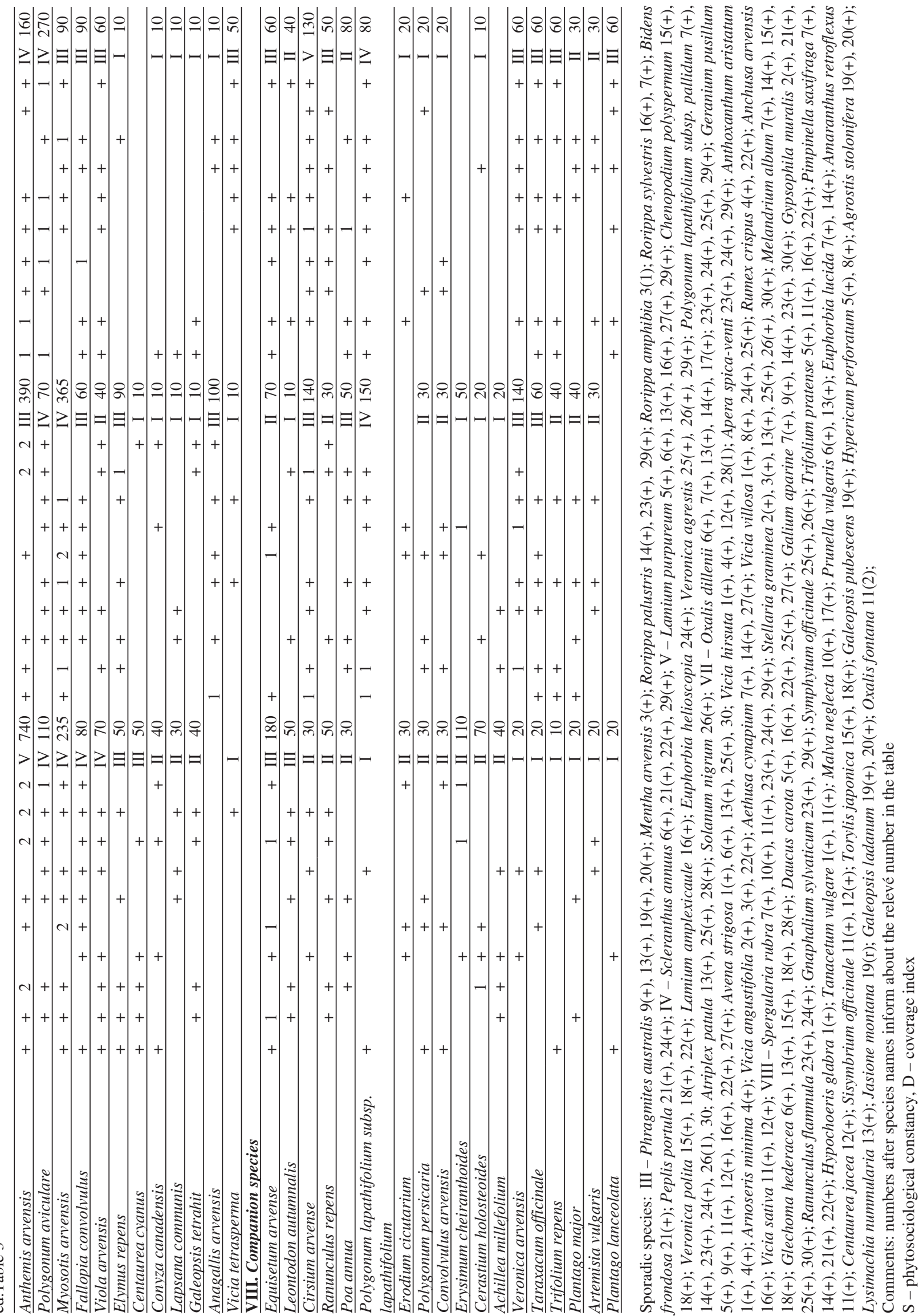


Table 4

Community with Veronica agrestis

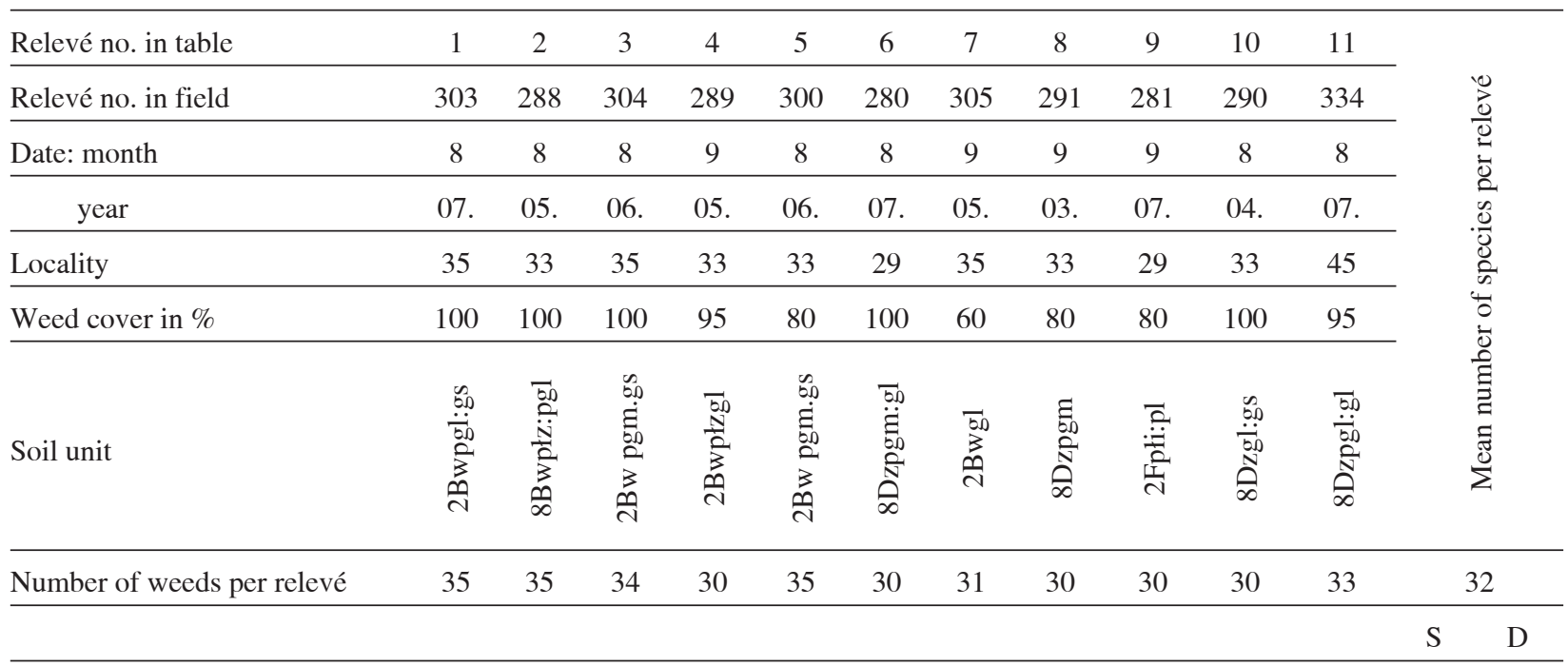

I. Ch. Polygono-Chenopodion

Polygono-Chenopodietalia

\begin{tabular}{|c|c|c|c|c|c|c|c|c|c|c|c|c|c|}
\hline Veronica agrestis & 2 & 3 & 1 & 2 & 1 & 3 & 1 & 2 & 2 & 2 & 1 & $\mathrm{~V}$ & 1825 \\
\hline $\begin{array}{l}\text { Matricaria maritima } \\
\text { subsp. inodora }\end{array}$ & 2 & + & 3 & + & + & 2 & & + & + & 2 & 2 & $\mathrm{~V}$ & 1175 \\
\hline Sonchus arvensis & + & 2 & + & + & 1 & & 1 & 2 & & + & + & $\mathrm{V}$ & 500 \\
\hline Chenopodium album & 1 & 1 & + & & + & + & & 1 & + & 2 & 2 & $\mathrm{~V}$ & 540 \\
\hline Chenopodium polyspermum & 1 & + & 2 & 1 & & 1 & 1 & + & + & 1 & + & $\mathrm{V}$ & 465 \\
\hline Euphorbia helioscopia & 2 & & 1 & & + & 1 & & + & 1 & + & & IV & 355 \\
\hline Lamium purpureum & 1 & + & 1 & & + & & 1 & + & & 1 & 1 & IV & 280 \\
\hline Lamium amplexicaule & & + & 1 & 1 & + & 1 & & + & & 1 & & IV & 230 \\
\hline Veronica polita & + & & & 1 & + & + & + & 1 & 1 & & + & IV & 200 \\
\hline Galinsoga parviflora & 1 & + & & + & + & & + & & & + & 1 & IV & 150 \\
\hline Atriplex patula & & + & 1 & + & & + & + & & + & + & + & IV & 120 \\
\hline Veronica persica & + & + & + & & & 1 & & + & & + & + & IV & 110 \\
\hline Echinochloa crus-galli & 1 & & + & & & + & + & & + & + & + & IV & 110 \\
\hline
\end{tabular}

\section{D. Hygrophilous species}

\begin{tabular}{lllllllllllllll}
\hline Rorippa sylvestris & 2 & + & 1 & 1 & 1 & 1 & + & + & + & & + & V & 425 \\
\hline Mentha arvensis & 1 & 1 & & + & & & 1 & + & 1 & 2 & & IV & 395 \\
\hline Potentilla anserina & 2 & 2 & 1 & 1 & 1 & + & 1 & 1 & & + & & IV & 62 \\
\hline Stachys palustris & & + & & 1 & & 2 & & + & + & & & III & 255 \\
\hline Sagina procumbens & 1 & & 1 & & + & & & & & + & + & III & 130 \\
\hline Polygonym amphibium & 2 & 2 & & & + & & & 1 & & & II & 410 \\
\hline
\end{tabular}

\section{Ch. Stellarietea mediae}

\begin{tabular}{|c|c|c|c|c|c|c|c|c|c|c|c|c|c|}
\hline Anagallis arvensis & 1 & + & 2 & 1 & + & + & 1 & & & 1 & + & V & 415 \\
\hline Elymus repens & + & 2 & 2 & 2 & 1 & + & & 1 & 1 & 3 & 1 & V & 1120 \\
\hline
\end{tabular}


cd.Table 4

\begin{tabular}{|c|c|c|c|c|c|c|c|c|c|c|c|c|c|}
\hline Stellaria media & + & 3 & 2 & + & + & 1 & 1 & 1 & 1 & + & + & $\mathrm{V}$ & 800 \\
\hline Chaenorhinum minus & 2 & & + & 1 & 2 & & & + & 1 & & 1 & IV & 520 \\
\hline Solanum nigrum & 2 & 2 & + & 1 & + & & 1 & & & 1 & + & IV & 530 \\
\hline Galinsoga ciliata & & + & & 1 & & 1 & & + & 1 & & 1 & III & 220 \\
\hline Myosotis arvensis & 1 & 1 & + & + & + & 1 & & & & + & + & IV & 200 \\
\hline Melandrium noctiflorum & 1 & + & + & 1 & + & & 1 & & + & + & & IV & 200 \\
\hline Viola arvensis & & + & + & + & & & + & 1 & + & + & + & IV & 120 \\
\hline Fallopia convolvulus & & + & + & & & + & + & + & & 1 & + & IV & 110 \\
\hline Aethusa cynapium & & 1 & 1 & 1 & & & & + & + & & & III & 170 \\
\hline Oxalis fontana & & & + & & 1 & 1 & + & & + & & & III & 130 \\
\hline Vicia tetrasperma & & & & + & + & & & & & + & + & II & 40 \\
\hline $\begin{array}{l}\text { Polygonum lapathifolium subsp. } \\
\text { pallidum }\end{array}$ & + & & + & & + & & & & + & & & II & 40 \\
\hline Capsella bursa-pastoris & + & + & & & & & & + & & & & II & 30 \\
\hline Polygonum aviculare & & & & + & & & & + & & + & & II & 30 \\
\hline Geranium pusillum & & + & + & & & & & + & & & & II & 30 \\
\hline \multicolumn{14}{|l|}{ IV. Companion species } \\
\hline Taraxacum officinale & + & & + & & & + & + & + & + & + & & IV & 70 \\
\hline $\begin{array}{l}\text { Polygonum lapathifolium subsp. } \\
\text { lapathifolium }\end{array}$ & 1 & & & & + & + & + & & . & + & + & III & 100 \\
\hline Cirsium arvense & + & & & + & + & + & & & + & & + & III & 60 \\
\hline Veronica arvensis & & & + & & + & + & & & & + & + & III & 50 \\
\hline Galium aparine & 1 & & & & 1 & + & & & + & & & II & 120 \\
\hline Equisetum arvense & & + & & & & + & + & & & & + & II & 40 \\
\hline Trifolium repens & & & + & & & + & + & & & & + & II & 40 \\
\hline Polygonum persicaria & + & + & & & & & & + & + & & & II & 40 \\
\hline Galeopsis bifida & & + & & & & + & + & + & & & & II & 40 \\
\hline Daucus carota & & & & & + & & & + & & + & & II & 30 \\
\hline Plantago major & & & + & & + & + & & & & & & II & 30 \\
\hline Gypsophila muralis & & & & + & & & + & & & & + & II & 30 \\
\hline Роа аппиа & + & & & & & + & + & & & & & II & 30 \\
\hline
\end{tabular}

Sporadic species: I - Setaria pumila 1(+), 10(+); II - Polygonum hydropiper 5(+); III - Vicia hirsuta 1(+); Conyza canadensis 4(+), 7(+); Centaurea cyanus 4(+); 2(+), Anthemis arvensis 2(+), 11(+); Anchusa arvensis 2(+); Apera spica-venti 9(+); IV - Erodium cicutarium $2(+)$; Leontodon autumnalis 11(+); Rorippa palustris 9(10); Veronica serpyllifolia 5(+); Convolvulus arvensis 2(+), 9(+); Achillea millefolium 2(+), 5(+); Cerastium holosteoides 2(+), 5(+); Ranunculus flammula 9(+); Galeopsis tetrahit 7(+); Galeopsis pubescens 6(+); Avena strigosa 5(+); Symphytum officinale 3(+), 10(+); Spergularia rubra 9(+); Stellaria graminea 10(+), 11(+); Ranunculus repens 5(+), 9(+); Melandrium album 5(+); Trifolium pratense $3(+), 8(+)$; Lapsana communis $7(+)$; Rumex obtusifolius $7(+)$; Rumex acetosa 7(+); Pimpinella saxifraga 7(+); Erysimum cheiranthoides 4(+); Sisymbrium officinale 1(+), 3(+);

Comments: numbers after species names inform about the relevé number in the table

$\mathrm{S}$ - phytosociological constancy, D - coverage index 


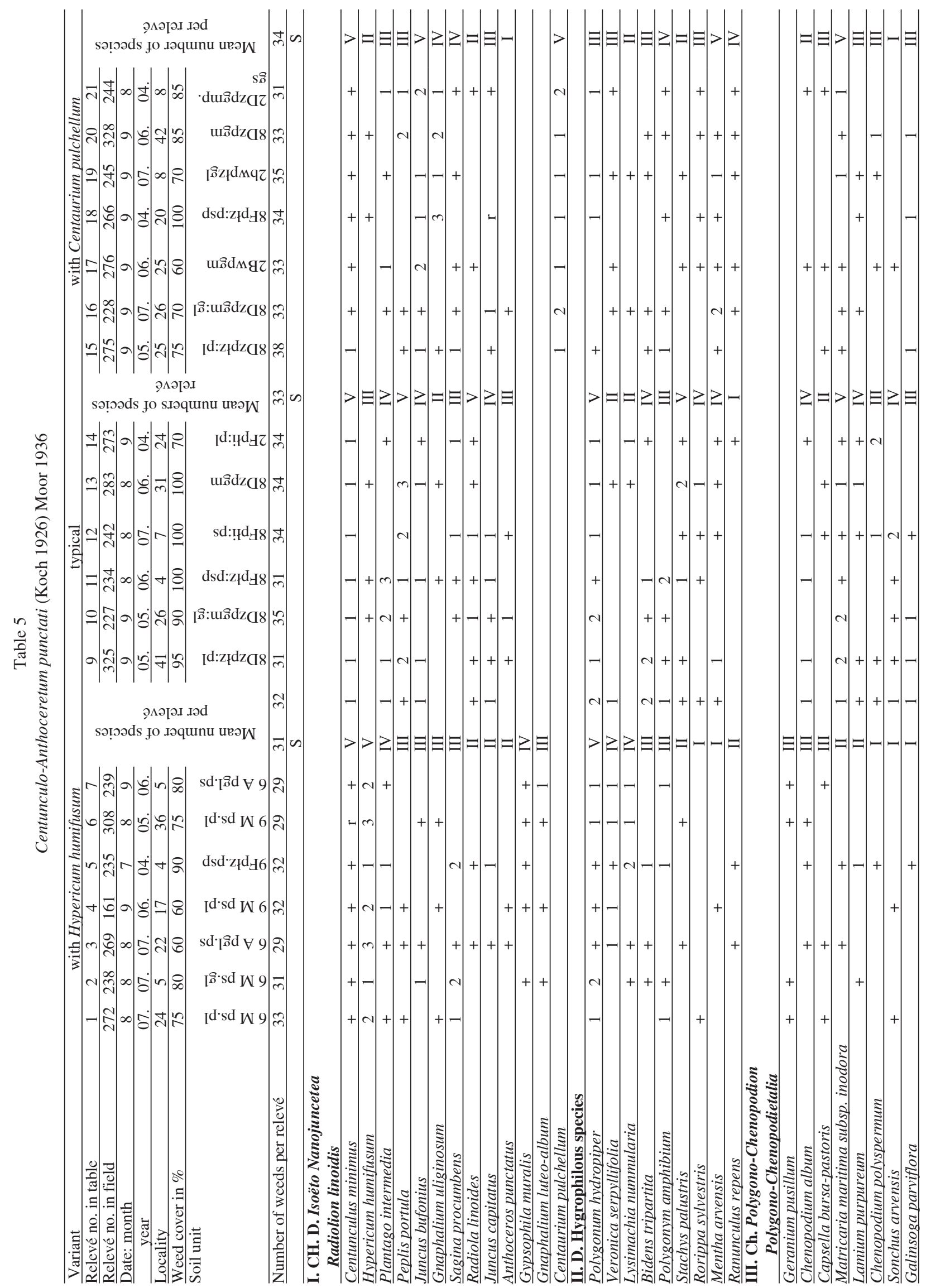




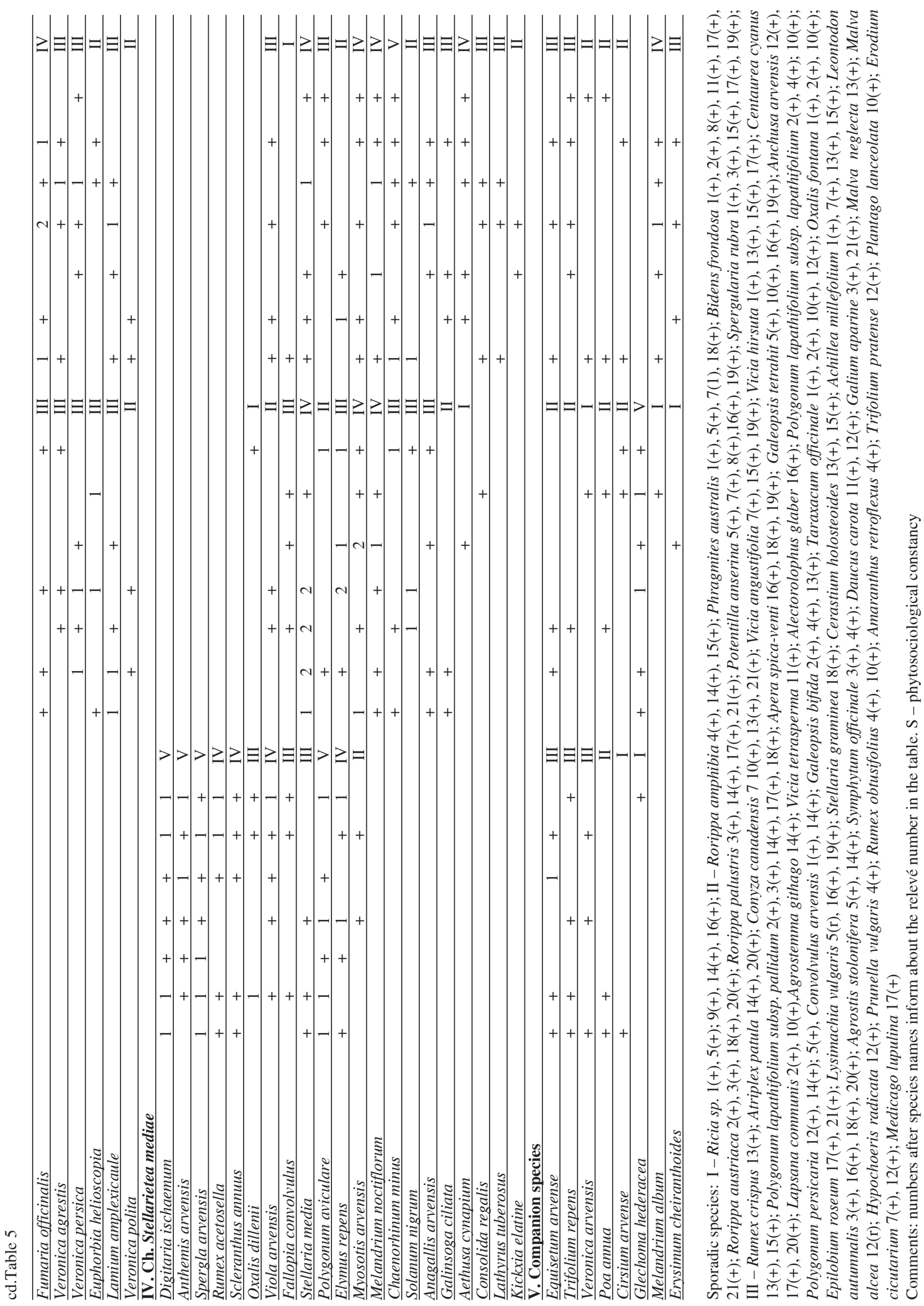


Chenopodium polyspermum, Chenopodium album, Euphorbia helioscopia, Veronica persica, Lamium purpureum, Lamium amplexicaule. Moreover, some species of higher syntaxonomic units were frequently noted, e.g.: Stellaria media, Elymus repens, Anagallis arvensis, Chaenorchinum minus, Solanum nigrum, Melandrium noctiflorum, Galinsoga ciliata. In the floristic composition, a high percentage of hygrophilous species was also observed, e.g.: Rorippa sylvestris, Mentha arvensis, Potentilla anserina, Stachys palustris, while locally Polygonum amphibium and Sagina procumbens. The phytocoenoses developing on rich soils of good wheat and strong cereal-fodder complex had optimal growth conditions. They were observed in the vicinity of Regut village (Polana Ponurzycka) and in Osieck. This phytocoenosis was represented by 11 vegetation patches. It is one of the floristically richest stubble field communiies in the studied area. In total, 80 species were noted in it, on average 32 in one relevé.

Centunculo-Anthoceretum punctati (Koch 1926) Moor 1936

In cereal stubble fields of the Mazowiecki Landscape Park and its buffer zone, patches of the association dominated by small therophytes and few mosses were rarely noted (Table 5). They were mainly recorded in local depressions and furrows. These small-area phytocoenoses developed in various habitat conditions that resulted in their floristic diversity and, as a consequence, in the division into lower syntaxa (variants). Patches of the variant with Hypericum humifusum were distinguishable by a low cover of Centunculus minimus - the species characteristic of this association and - the mass occurrence of Hypericum humifusum (differential species). A high proportion of acidophilus species was also observed, e.g. Spergula arvensis, Rumex acetosella, Digitaria ischaemum, Scleranthus annuus, and Anthemis arvensis. The community was noted on soils developed from muck sands classified as weak rye and weak cereal-fodder complexes.

Patches of the typical variant were noted in stubble fields on compact soils included in the strong cereal-fodder complex. They were characterized by the largest cover of Centunculus minimus and the numerous occurrence of the species characteristic for higher syntaxonomic units: Radiola linoides, Peplis portula, Plantago intermedia, Juncus bufonius, Juncus capitatus and Sagina procumbens. Moreover, their physiognomy was highly affected by strongly expanding, deep-root, hygrophilous species, e.g. Polygonum hydropiper, Bidens tripartita, Polygonum amphibium, Stachys palustris, Veronica serpyllifolia, as well as by nitrophilous species, e.g. Matricaria maritima subsp. inodora, Chenopodium album, Chenopodium polyspermum, Lamium purpureum,Euphorbia helio- scopia, Solanum nigrum, Fumaria officinalis. Patches with the mass occurrence of Centaurium pulchellum were observed in similar habitats, differing in a higher concentration of $\mathrm{CaCO}_{3}$. Apart from the numerous occurrence of nitrophilous weeds, they were marked by the highest cover of moderately calciphilous taxa, e.g.: Consolida regalis, Aethusa cynapium, Melandrium album, Chaenorhinum minus, as well as the occurrence of Lathyrus tuberosus and Kickxia elatine - species not recorded in other stubble field phytocoenoses under investigation.

Centunculo-Anthoceretum punctati was floristically the richest association from among the identified syntaxa, comprising 114 species. The average number of species varied from 31 in the variant with Hypericum humifusum to 34 in the variant with Centaurium pulchellum.

\section{DISCUSSION}

Cereal stubble fields situated in the agricultural areas of the Mazowiecki Landscape Park and its buffer zone are frequently left unploughed. Floristically rich communities developing there reflect different trophic and moist habitat conditions. Data on high floristic biodiversity of stubble field communities have been reported from many regions of Poland and from abroad (J ę d ru s zczak, 1990; P aw łow ski and J ędruszczak, 1986; Wnuk, 1988; P awłowski et al. 1994; Trąba, 1991, 1993; W a rcholińska, 1994; Skrajna and Skrzyczyńska , 2002; Rzymowska and S k r z y c z y ń s k a, 2006a,b; Di er s c h ke, 2010). Extensive agriculture and diversified habitat conditions in the studied area have resulted in great internal differentiation of the developing communities. The floristically richest patches of the Centunculo-Anthoceretum punctati association, rarely recorded in this region and considered to be in danger of extinction in Poland (Ć w i k li ńs ki , 1982; G ł ow a c k i et al. 2003; T r ą b a , 1993; W a r c h o li ń s k a , 1988; S kraj n a, 2006), were seldom observed within the Park area. Phytocoenoses of another floristically rich community with Veronica agrestis were also only sporadically noted in the studied stubble fields. The occasional occurrence of these phytocoenoses results from a low proportion of fertile soils in the study area. In their floristic composition, these plots resemble the phytocoenoses classified as the communities with Veronica persica, frequently occurring in stubble fields of the Lublin region (J ę d r u s z c z a k et al. 1989), southeastern Poland (Trąb a, 1991; Tr ą b a, 1993), the western part of the Siedlce region ( $\mathrm{S} \mathrm{k} \mathrm{r} \mathrm{z} \mathrm{y} \mathrm{c} \mathrm{z} \mathrm{y} \mathrm{ń} \mathrm{s} \mathrm{k} \mathrm{a}$ and R z y m o w s k a, 1997), the Kałuszyńska Upland (Skrajna and Skrzyczyńska, 2005), as well 
as the Podlaski Przełom Bugu mesoregion (R zy mow s ka and Skrzy czyńs ka, 2006b). Patches of the community with Setaria pumila, the form with Aphanes arvensis, were also rarely noted. They were distinguishable by the mass occurrence of Aphanes arvensis, the species found outside its geographical range. On the other hand, the typical form of the community with Setaria pumila was frequently noted in the studied area. This community is considered to be common and species diversified in stubble fields in other regions of Poland ( $\mathrm{P} \mathrm{a} \mathrm{w} \mathrm{ow} \mathrm{s} \mathrm{k} \mathrm{i} \mathrm{and} \mathrm{T} \mathrm{r} \mathrm{ą} \mathrm{b} \mathrm{a} \mathrm{,} \mathrm{1987;}$ Trą b a , 1991, 1993; J ę d r u s z c z a k et al. 1990; Skrajna and Skrzyczyńska, 2002; Rzymowska and Skrzyczyńska, 2006b). Echinochloo-Setarietum is considered the most common and, floristically, most diversified weed community of root crops in Poland and abroad. In the studied area, this association was also frequently noted in stubble fields on fertile soils, whereas in the poorest habitats the Digitarietum ischaemi association was predominant (W nuk, 1988; J ę d r u s z c z a k et al., 1989; A n i o ł- K w i a t k o w s k a, 1990; J ę d r u s z c z a k, 1990b; Pawłowski et al. 1991; Trąba, 1993; Warcholińska, 1994; S krzyczyńska and R z y m ow s ka, 1997; M o c hn a cky, 2000; S krajna and Skrzyczyńska, 2002; Skrajna and Skrzyczyńska, 2005; Rzy mow ska and Skrzyczyńs ka, 2006, 2006a; P inke and Pal, 2008). The frequent occurrence of the floristically poorest variant of the association with Anthoxanthum aristatum within the Park area is also noteworthy. The mass occurrence of Anthoxanthum aristatum in the patches affects the floristic composition of the phytocoenoses, which results in significant degeneration of the community. A similar process was previously observed in the patches of Arnoserido-Scleranthetum, var. with Anthoxanthum aristatum, in cereal crops (S kraj na et al., 2009). Information on the impoverishment of communities due to the intensive occurrence of Anthoxanthum aristatum was also reported by W a r c holi ń s k a (1994) from Piotrków Plateau.

\section{CONCLUSIONS}

1. Three plant associations classified into lower syntaxonomic units (variants): Digitarietum ischaemi, Echinochloo-Setarietum, Centunculo-Anthoceretum punctati, and two communities with Setaria pumila and with Veronica agrestis. were identified in the unploughed stubble fields of the Mazowiecki Landscape Park.

2. Well-developed patches of the association Centunculo-Anthoceretum punctati and the community with Veronica agrestis were seldom noted in the studied stubble fields.
3. The associations Echinochloo-Setarietum on fertile soils and Digitarietum ischaemi in poor habitats were commonly observed.

4. Patches of the community Setaria pumila with Aphanes arvensis were sporadically noted in the south-eastern part of the Park.

\section{REFERENCES}

A nioł-Kwiatkowska J., 1990. Zbiorowiska segetalne Wału Trzebnickiego. Florystyczno-ekologiczne studium porównawcze. / Segetal comunities of the Trzebnica Moralne Belt. A floristic and ecological comparative study. Wyd. Univ. Wrocław. Prace Bot.: 46-230 (in Polish).

Ćwikliński E., 1982. Zespoły ścierniskowe Mińskiego Obszaru Chronionego Krajobrazu w województwie siedleckim. / Stubble-field communities in the Mińsk Protected Landscape Area in Siedlce Voivodship. Zesz. Nauk. WSR-P w Siedlcach, Rolnictwo, (1): 275-288 (in Polish).

D i e r s ch ke H., 2010. Über 80 Jahre wissenschaftliche Begleitung phlanzensoziologischer Feldforchung in Mitteleuropa-Übersicht der in den Mitteilungen und in Tuexenia publizierten Vegetationsaufnahmen (1928-2009). Texenia, 30: 319-348.

Głowacki Z., Falkowski M., Krechowski J., Marciniuk J., Marciniuk P., Nowicka-Falkowsk a K., W i e r z b a M., 2003. Czerwona lista roślin naczyniowych Niziny Południowopodlaskiej. / The red list of vascular plants of South Podlasie Lowland. Chrońmy Przyrodę Ojczystą 59 (2): 5-41 (in Polish).

Jędruszczak M. Pawłowski F., Wójcik Z., 1989. Zbiorowiska roślinne ściernisk Lubelszczyzny. Cz. I. Zbiorowiska siedlisk ubogich. / Plant communities of stubble fields in the Lublin Region. P. I. Plant communities of poor sites. Acta Agrobot. $42(1,2)$ : 207-228 (in Polish).

J ę d r u s zc zak M., 1990. Zbiorowiska roślinne Lubelszczyzny. Cz. III. Zbiorowiska siedlisk bogatych i wilgotnych. / Plant communities of stubble fields in the Lublin Region, P. III. Plant communities of rich and humid sites. Acta. Agrobot. $43(1,2)$ : 155-172.

Jędruszczak M., 1997. Reprodukcja generatywna chwastów na ścierniskach po jęczmieniu jarym. / Generative reproduction of weeds in stubble fields after spring barley. Mat. XXI Kraj. Konf. „Zachwaszczenie wtórne roślin okopowych i ściernisk". IUNG Puławy: 135-144 (in Polish).

Mat u s z k i ew i c z W., 2001. Przewodnik do oznaczania zbiorowisk roślinnych Polski. Państwowe Wydawnictwo Naukowe, Warszawa (in Polish).

Mirek Z., Piękoś-Mirkowa H., Zając M., 2002. Flowering plants and peridophytes of Poland. A checklist. Kraków: 1-442.

Mochnack y S., 2000. Syntaxonomy of segetal communities of Slovakia. Thaiszia 9: 149-204. 
Pawłow sk i B., 1972. Skład i budowa zbiorowisk roślinnych oraz metody ich badania. [In:] Szata roślinna Polski. Państwowe Wydawnictwo Naukowe, 1: 237-268.

Pawłowski F., Kapeluszy J., Kolasa A., Lecyk Z., 1970. Płodność chwastów na ścierniskach w woj. Lubelskim. / Fertility of weeds in stubble fields of the Lublin Province. Ann. UMCS, E, XXV(4): 49-59 (in Polish).

Pawłowski F., Trąba Cz., Wójcik, 1991. Zbiorowiska roślinne ściernisk na nizinnych kompleksach gleboworolniczych południowo-wschodniej Polski. Cz. I. Zbiorowiska związku Panico-Setarion. / Stubble-field plant communities in lowland agricultural soil complexes in South-Eastern Poland. P. I. Plant communities of the Panico-Setarion alliance. Acta Agrobot. 44 (1-2): $87-$ 111 (in Polish).

Pawłowski F., Jędruszczak M., B ojarczyk M., Maj d a J., 1994. Chwasty ściernisk zbożowych na różnych glebach Kielecczyzny. Cz I. Gleby bielicowe i brunatne wytworzone z piasków i glin. / Weeds of cereal stubble fields on various soils in the Kielce region. P. I. Podzolic and brown soils developed from sands and loams. Acta Agrobot. 47 (2): 13-26 (in Polish).

Pawłowski F., Jedruszczak M., 1986. Zachwaszczenie ściernisk zbożowych Lubelszczyzny. / Weed infestation of cereal stubble fields in the Lublin region. Acta Agrobot. 39 (1): 143-164 (in Polish).

Pawłowski F., Trąba Cz., 1987. Zachwaszczenie ściernisk zbożowych na niektórych glebach w południowowschodniej Polsce. Cz. I. Gleby terenów nizinnych. / Weed infestation of cereal stubble fields on selected soil types in south-eastern Poland. Part I. Soils of lowland regions. Ann. UMCS, E, XLII (9): 83-98 (in Polish).

Pinke G., Pal R., 2008. Phytosociological and conservational study of the arable weed communities in western Hungary. Plant Biosystems, 142 (3): 491-508.

R z y mowska Z ., S k r z y c z y ń sk a J., 2006 a. Zbiorowiska roślinne pól uprawnych Podlaskiego Przełomu Bugu. Cz. III. Zbiorowiska ścierniskowe gleb piaszczystych. / Plant communities of cultivated fields of the Podlaski Przełom Bugu mesoregion. Part.3 Stubble-field communities on sandy soils. Acta Agrobot. 59 (2): 393-419 (in Polish).

Rzymowska Z., Skrzyczyńska J., 2006 b. Zbiorowiska roślinne pól uprawnych Podlaskiego Przełomu Bugu. Cz. IV. Zbiorowiska ścierniskowe gleb zwięzłych. / Plant communities of cultivated fields of the Podlaski Przełom Bugu mesoregion. Part.4 Stubblefield communities on compact soils. Acta Agrobot. 59 (2): 421-440 (in Polish).

S k rajn a T., S k r z y c z y ń s k a J., 2002: Roślinność ściernisk gminy Grębków. / The vegetation of stubble fields of the Grębków commune. Zesz. Nauk. AP, Siedlce, ser: Rolnictwo, 61: 5-14 (in Polish).

Skrajna T., Skrzyczyńska J., 2003. Chwasty ściernisk Wysoczyzny Kałuszyńskiej. / Weeds of stubble fields of the Kałuszyńska Upland. Zesz. Nauk AP Siedlce, ser Rolnictwo, 63: 59-69 (in Polish).
Skrajna T., 2006. Zbiorowiska roślinne agrocenoz gminy Korytnica (województwo mazowieckie). Cz. II. Zbiorowiska i zespoły ściernisk. / Plant communities in agrocenoses of Korytnica commune (Mazovian voivodeship). Part. II Stubble-field communities and associations. Zesz. Nauk AP, Siedlce, ser. Rolnictwo 74-75: 75-86 (in Polish).

Skrajna T,, Skrzyczyńska J., Ługowska M., 2009. Segetal communities of cereal crops of the Mazowiecki Landscape Park. Acta Agrobot. 62 (1): 171-186.

Skrzyczyńska J,, Rzy mowska Z., 1997. Zbiorowiska roślinne w zachodniej części woj. siedleckiego. [In:] Zachwaszczenie wtórne roślin okopowych i ściernisk. Materiały Krajowej Konferencji IUNG, Wrocław, Wydawnictwo IUNG Puławy: 153-161 (in Polish).

Trąb a Cz., 1991. Zbiorowiska roślinne ściernisk w południowo-wschodniej Polsce. Cz. IV. Zbiorowiska ze związku Nanocyperion flavescentis. / Stubble-field plant communities in south-eastern Poland. P. I. Plant communities of the Nanocyperion flavescentis alliance. Acta. Agrobot., 44 (1, 2): 171-193 (in Polish).

Trąba Cz., 1993. Zbiorowiska roślinne ściernisk w południowo-wschodniej Polsce. Cz. V. Charakterystyka porównawcza zbiorowisk ścierniskowych. / Stubble-field plant communities in south-eastern Poland. Part V. The comparative characteristics of stubble-field plant communities. Acta. Agrobot. 46 (1): 99-127 (in Polish).

Trą b a Cz., Zie mińsk a M., 1994. Nie podorane ścierniska źródłem zachwaszczenia pól uprawnych. / Unploughed stubbles as a source of weed infestation of cultivated fields. Mat. XVII Kraj. Konf. „Przyczyny i źródła zachwaszczenia pól uprawnych”, Wyd. ART Olsztyn-Bęsia: 101:108 (in Polish).

Wa r choli ńska A. U., 1988. Roślinność segetalna terenów rolniczych Puszczy Bolimowskiej i jej współczesne przemiany. / Segetal vegetation of agricultural areas of Bolimów Primeval Forest and its contemporary transformations. Acta. Agrobot. 41 (2): 369-452 (in Polish).

Warcholińska A. U., 1994. Zmiany roślinności segetalnej Równiny Piotrkowskiej w ostatnich 22 latach. Cz. III. Zbiorowiska chwastów ściernisk. / Changes in segetal vegetation of the Piotrków Plain during the last 22 years. Part III. Weed communities of stubble fields. Acta. Agrobot. 47 (1): 55-65 (in Polish).

Wnu k Z., 1988. Zbiorowiska segetalne Wyżyny Częstochowskiej na tle zbiorowisk segetalnych Polski. / Segetal communities of the Częstochowa Upland against the background of segetal communities in Poland. Zesz. Nauk. Akademii Rol. im. H. Kołłątaja w Krakowie, rozp. nr 125: 1-33 (in Polish). 


\section{Zbiorowiska roślinne ściernisk Mazowieckiego Parku Krajobrazowego}

\section{Streszczenie}

W pracy przedstawiono charakterystykę zbiorowisk wykształcających się na niezaoranych ścierniskach Mazowieckiego Parku Krajobrazowego i w jego rolniczej otulinie. Najczęściej notowanym i zróżnicowanym florystycznie był zespół Echinochloo-Setarietum, w którym wyróżniono wariant typowy, wariant z Galinsoga parviflora i wariant z Bidens tripartita. Częstymi fitocenozami badanego terenu były również płaty Digitarietum ischaemi porastające ścierniska na najuboższych siedliskach. Rzadko i na niewielkich powierzchniach, na glebach żyznych spotykano bogate florystycznie płaty zbiorowiska z Veronica agrestis. Gleby okresowo nadmiernie uwilgotnione porastały rzadko spotykane i najbogatsze gatunkowo fitocenozy Centunculo-Anthoceretum punctati. Jedynie w południowo-wschodniej części Parku występowały pojedyncze płaty zbiorowiska z Setaria pumila postać $\mathrm{z}$ Aphanes arvensis. 
